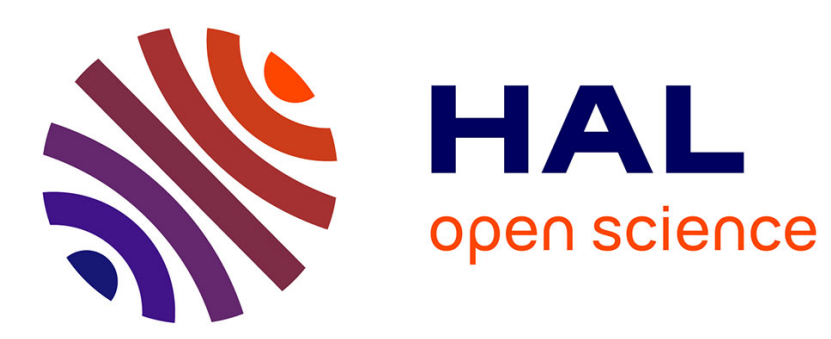

\title{
Ultrasonic investigation of rotational isomerism on mesomorphic compounds
}

S. Candau, P. Martinoty, R. Zana

\section{To cite this version:}

S. Candau, P. Martinoty, R. Zana. Ultrasonic investigation of rotational isomerism on mesomorphic compounds. Journal de Physique Lettres, 1975, 36 (1), pp.13-15. 10.1051/jphyslet:0197500360101300 . jpa-00231139

\section{HAL Id: jpa-00231139 https://hal.science/jpa-00231139}

Submitted on 1 Jan 1975

HAL is a multi-disciplinary open access archive for the deposit and dissemination of scientific research documents, whether they are published or not. The documents may come from teaching and research institutions in France or abroad, or from public or private research centers.
L'archive ouverte pluridisciplinaire HAL, est destinée au dépôt et à la diffusion de documents scientifiques de niveau recherche, publiés ou non, émanant des établissements d'enseignement et de recherche français ou étrangers, des laboratoires publics ou privés. 


\title{
ULTRASONIC INVESTIGATION OF ROTATIONAL ISOMERISM ON MESOMORPHIC COMPOUNDS $(*)$
}

\author{
S. CANDAU, P. MARTINOTY
}

Laboratoire d'Acoustique Moléculaire, Université Louis-Pasteur

4, rue Blaise-Pascal, 67070 Strasbourg Cedex, France

and

R. ZANA

Centre de Recherches sur les Macromolécules

6, rue Boussingault, 67083 Strasbourg Cedex, France

(Reçu le 11 octobre 1974)

\begin{abstract}
Résumé. - Le coefficient d'absorption d'ondes ultrasonores longitudinales a été mesuré en fonction de la fréquence et de la température dans la phase nématique du $\mathrm{p}$ méthoxy $\mathrm{p}^{\prime} \mathrm{n}$ butyl azoxybenzène (Licristal Merck IV). Pour des températures beaucoup plus basses que la température de transition nématique-isotrope, la variation de l'absorption avec la fréquence obéit à une loi de relaxation unique. La variation thermique de la fréquence de relaxation peut être interprétée à partir de l'isomérie de rotation dans les groupes terminaux flexibles des molécules.
\end{abstract}

Abstract. - The attenuation coefficient of ultrasonic longitudinal waves in the nematic phase of the $p$ methoxy $p^{\prime} n$ butyl azoxybenzene (Licristal Merck IV) has been measured as a function of both frequency and temperature. For temperatures far below the nematic-isotropic transition, the frequency dependence of the attenuation can be accounted for by a single relaxational process. The temperature dependence of the relaxational frequency appears to support the assumption of rotational isomerism in the flexible ends of the molecules.

The ultrasonic properties of liquid crystals have been examined by several investigators [1-11]. Most of the studies have been performed in the vicinity of the nematic-isotropic transition temperature $T_{\mathrm{c}}$ where the sound wave propagation shows anomalous behaviour characterized by a sharp maximum of the low frequency attenuation and a sharp minimum of the velocity. In that temperature range the ultrasonic properties are characteristic of a multiply relaxing fluid. The averaged relaxation frequency diverges at $T_{\mathrm{c}}$.

Experiments performed on the p-methoxybenzylidene $p$-n butyl aniline (MBBA) have shown that, even at temperatures far below the transition temperature $\left(T<T_{\mathrm{c}}-20^{\circ}\right)$ a strong relaxational contribution to the attenuation still subsists, whose frequency dependence is satisfactorily described by a single relaxation [7, 12].

This relaxational process has been assigned to the perturbation by the sound wave of an intramolecular equilibrium [12,13]. The MBBA, as well as all the

(*) Work partially supported by D. R. M. E. Contract 71/034 mesomorphic compounds, consists of molecules having a rigid central part and two flexible end groups. Some of the possible conformations of these end groups differ in their free energy and then are acoustically effective. The internal relaxational process was first assigned to a cis-trans equilibrium of the methoxy group [12] (see Fig. 1) by analogy with esters or vinyl-ethers where relaxational processes have been observed in the range of $1-100 \mathrm{MHz}$ [14]. In those compounds, the barrier for the rotation arises from the partial double bond

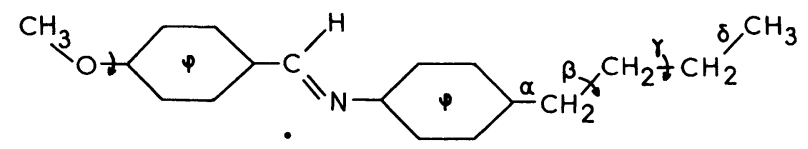

Para Methoxy benzylidene p'n bulylaniline (M.B.B.A.)

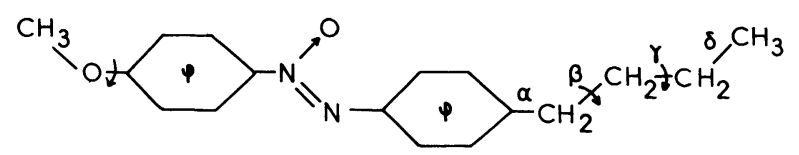

Para Methoxy p'n butylazoxybenzene (Licristal Merck IV)

FIG. 1. - Molecules of MBBA and Licristal Merck IV. The arrows indicate the acoustically effective rotational isomerisms. 
character of the $\mathrm{C}-\mathrm{O}$ bond owing to the delocalization of the $\pi$ electrons. In the molecule of MBBA, the $\pi$ electrons are also delocalized owing to the conjugation. However, as there are no steric interactions, the free energy difference between the cis and trans forms should be negligible and then, the ultrasonic attenuation would be very small.

Another possibility which has been suggested by Jähnig is that the relaxational process arises from transgauche transitions in the butyl chain at the other end of the molecules, the possible conformations corresponding to those of pentane. As the paraffine chain has a number of different energy levels one would expect a distribution of relaxation frequencies except, if one relaxation process is predominant in the available frequency range. In pentane, the relaxation is assumed to arise from the rotation between trans-gauche and trans-trans conformations [15] (see Fig. 2).

A check of the validity of the assumption of rotational isomerism can be obtained from the temperature dependence of the relaxation frequency. One knows from the theory of rate processes [16] that the characteristic frequency of an internal two state equilibrium can be given in terms of an increase in free energy $\Delta G_{\mathrm{b}}$ on moving from the higher energy state to an intermediate activated state

$$
\begin{aligned}
& f_{\mathrm{r}} \simeq \frac{k_{\mathrm{B}} T}{2 \pi} \exp \left(-\Delta G_{\mathrm{b}} / R T\right) \\
& f_{\mathrm{r}} \simeq \frac{k_{\mathrm{B}} T}{2 \pi} \exp \left(\Delta S_{\mathrm{b}} / R\right) \exp \left(-\Delta H_{\mathrm{b}} / R T\right) .
\end{aligned}
$$

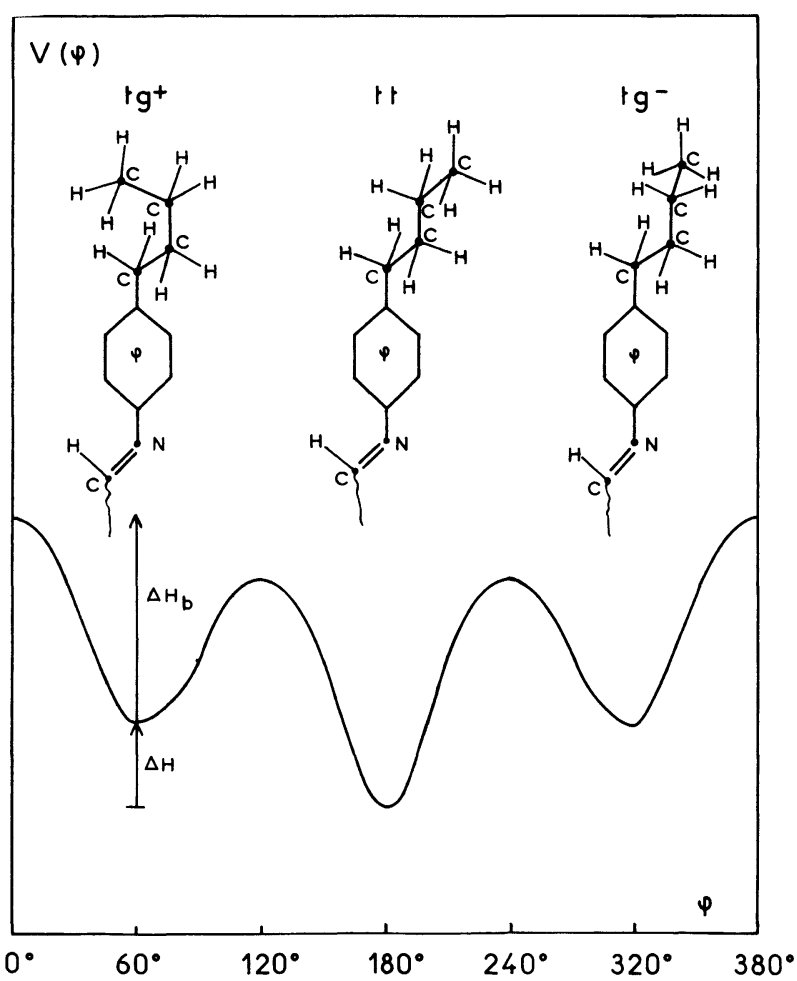

Fig. 2. - Potential energy $V(\varphi)$ as a function of angular displacement $\varphi$ for internal rotation around the $\gamma(\mathrm{C}-\mathrm{C})$ bond. The trans-gauche $^{+}$and trans-gauche ${ }^{-}$levels are of equal energy.
The entropy barrier $\Delta S_{\mathrm{b}}$ and the enthalpy barrier $\Delta H_{\mathrm{b}}$ can be determined from the slope and intercept of a graph of $\log \left(f_{\mathrm{r}} / T\right)$ against $10^{3} / T$.

Such a temperature dependence of the relaxation frequency is not evident in MBBA where the dominant effect in the whole range of temperature is the critical one, the melting point $\left(22^{\circ} \mathrm{C}\right)$ being too close to the clearing temperature $\left(47^{\circ} \mathrm{C}\right)$.

In order to separate the contribution to the ultrasonic attenuation arising from the internal process we have investigated the acoustical properties of the $p$ methoxy $\mathrm{p}^{\prime} \mathrm{n}$ butyl azoxybenzene (Licristal Merck IV) which has the same end groups as the MBBA (Fig. 1) but is nematic in a much larger temperature range $\left(16^{\circ} \mathrm{C}\right.$ to $\left.76^{\circ} \mathrm{C}\right)$.

The sample investigated was purchased from the Merck Company and used without further purification. The attenuation measurements were performed with a conventional pulse technique in the frequency range 5-155 MHz. The sample was unoriented.

Figure 3 shows the frequency dependence of the quantity $\alpha / f^{2}$ ( $\alpha$ sound attenuation, $f$ frequency) at $T=25^{\circ} \mathrm{C}$. The experimental data fits satisfactorily a curve calculated from the well known relationship for a single time relaxation process :

$$
\frac{\alpha}{f^{2}}=\frac{A}{1+\left(f / f_{\mathrm{r}}\right)^{2}}+B
$$

where $A$ and $B$ are constants and $f_{\mathrm{r}}$ is the relaxation frequency.

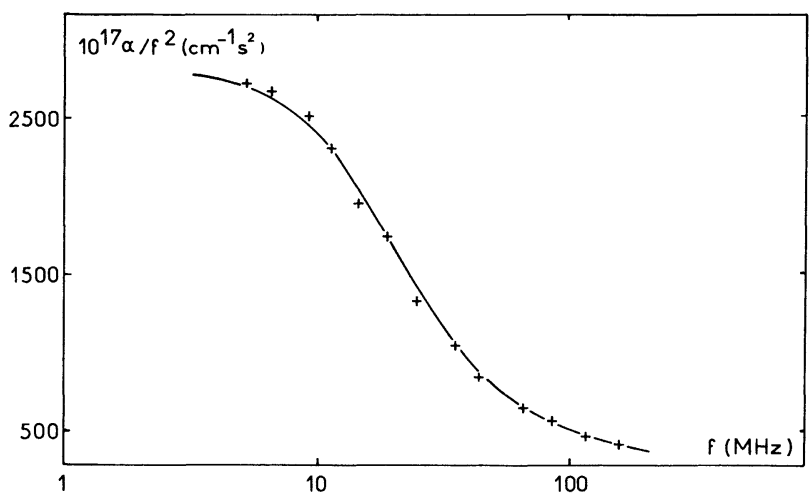

Fig. 3. - Licristal Merck IV Plot of $\alpha / f^{2}$ versus $f(+)$ : experimental data. The full line has been calculated from eq. (2).

In the temperature range $20{ }^{\circ} \mathrm{C}-41{ }^{\circ} \mathrm{C}$, when increasing the temperature, the relaxational frequency increases and the amplitude of the dispersion, that is, the coefficient $A$, decreases, in contrast with the behaviour in the vicinity of the transition point where $f_{\mathrm{r}}$ (an averaged $f_{\mathrm{r}}$ ) and $A$ respectively decrease and increase critically with temperature.

In figure 4 we have plotted $\log \left(f_{\mathrm{r}} / T\right)$ againt $10^{3} / T$. One obtains a straight line of negative slope in accordance with eq. (1). 
The slope and the intercept of the straight line, yields

$$
\begin{aligned}
& \Delta H_{\mathrm{b}}=3 \mathrm{kcal} / \mathrm{mole} \\
& \Delta S_{\mathrm{b}}=-11 \mathrm{cal} / \mathrm{mole} / \mathrm{K} .
\end{aligned}
$$

This value of $\Delta H_{\mathrm{b}}$ is in good agreement with that obtained for pentane [17] (3.3 kcal/mole) by means of infrared spectroscopy.

This agreement supports the assumption of conformational changes in the butyl chain of the Licristal IV molecule.

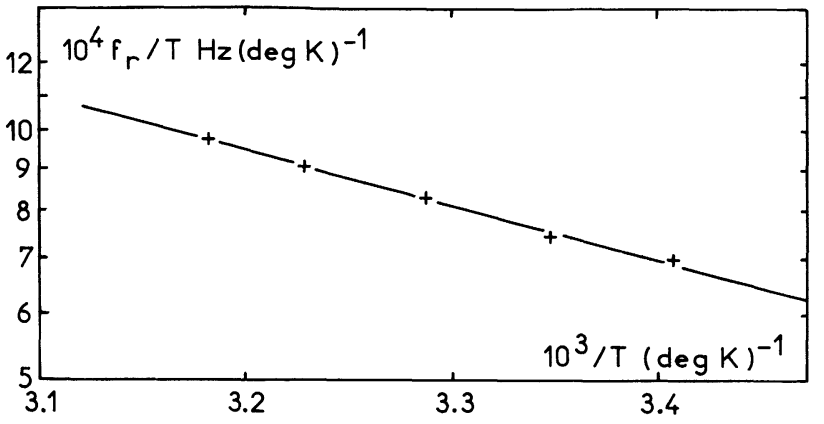

FiG. 4. - Licristal Merck IV Plot of $\log \left(f_{\mathrm{r}} / T\right)$ versus $10^{3} / T$.
The entropy barrier is not known for pentane, but its magnitude is certainly much lower that the value found in Licristal IV because the relaxation frequency of pentane at room temperature is much higher and out of the experimentally available range of frequencies [15], [18]. In other words, for n-pentane, the graph of $\log \left(f_{\mathrm{r}} / T\right)$ against $10^{3} / T$ would be a straight line parallel to that on figure 4 , but shifted upward. We must then assume that a change in the entropy barrier between states of different energy levels occurs when the paraffinic chain is attached to a molecule belonging to a nematic matrix. This effect is presumably related to the considerable ordering of the end chains which has been recently shown to exist in the mesomorphic phases $[19,20]$. In the light of these new results and as pointed out by Jähnig [13], it now appears that the conclusions reached in the study of MBBA and especially those concerning the divergence of the ultrasonic attenuation must be reexamined.

Acknowledgment. - The authors thank M. Kuhlwein for technical assistance.

\section{References}

[1] Hoyer, W. A. and Nolle, A. W., J. Chem. Phys. 24 (1956) 803.

[2] Edmonds, P. D. and OrR, D. A., Mol. Cryst. 2 (1966) 135.

[3] Natale, G. G. and Commins, D. E., Phys. Rev. Lett. 29 (1972) 1439.

[4] Martinoty, P. and Candau, S., C. R. Hebd. Séan. Acad. Sci. 271B (1970) 107.

[5] Lord, A. E. Jr, and Labes, M. M., Phys. Rev. Lett. 25 (1970) 570.

[6] Mullen, M. E., Lüthi, B. and Stephen, J. M., Phys. Rev. Lett. 28 (1972) 799.

[7] Eden, D., Garland, C. W. and Williamson, R. C., $J$. Chem. Phys. 58 (1973) 1861.

[8] BaCri, J. C., J. Physique 35 (1974) 601.

[9] Kawamura, Y., Maeda, Y., Okano, K. and Iwayanagi, S., Jap. J. of Appl. Phys. 12 (1973) 1510.

[10] Kapustin, A. P. and Bykova, N. T., Sov. Phys. Cristal. 11 (1966) 297.
[11] Kapustin, A. P. and Mart'yanova, L. J., Sov. Phys. Cristal. 16 (1971) 559.

[12] Martinoty, P., Thesis, Strasbourg (France), 1970.

[13] JÄHNIG, F., Preprint.

[14] Matheson, A. J., Molecular acoustics (J. Wiley and Sons) and references there in.

[15] Piercy, J. E. and Rao, M. G. S., J. Chem. Phys. 46 (1967) 3951.

[16] Glasstone, S., Laidler, K. J. and Eyring, H., Theory of Rate Processes (McGraw Hill, New York) 1941.

[17] Sheppard, N. and Szasz, G. J., J. Chem. Phys. 17 (1969) 86.

[18] Cochran, M. A., Jones, B. P., North, A. M. and Pethrick, R. A., J. Chem. Soc. 68 (1972) 1719.

[19] Marcelja, S., J. Chem. Phys. 60 (1974) 3599.

[20] Deloche, B., Charvolin, J., Liebert, L. and Strzelecki, L. Fifth Int. Liquid-Crystal Conf., Stockholm, June 1974. Tobe published in J. Physique Collq. 36 (1975) C1. 